\title{
Exploring resource efficiency for energy, land and phosphorus use: Implications for resource scarcity and the global environment
}

\author{
Maurits van den Berg ${ }^{\mathrm{a}, *}$, Kathleen Neumann ${ }^{\mathrm{a}, \mathrm{b}}$, Detlef P. van Vuuren ${ }^{\mathrm{a}, \mathrm{c}}$, A.F. Bouwman ${ }^{\mathrm{a}, \mathrm{d}}$, \\ Tom Kram ${ }^{a}$, Jan Bakkes ${ }^{a}$ \\ a PBL Netherlands Environmental Assessment Agency, PO Box 303, 3720 AH, Bilthoven, The Netherlands \\ ${ }^{\mathrm{b}}$ Wageningen University, Laboratory of Geo-information Science and Remote Sensing, P.O. box 47, 6700 AA Wageningen, The Netherlands \\ ${ }^{\mathrm{c}}$ Utrecht University, Copernicus Institute of Sustainable Development, Faculty of Geosciences, Postbus 80.115, 3508 TC Utrecht, The Netherlands \\ d Utrecht University, Department of Earth Sciences-Geochemistry, Faculty of Geosciences, P.O. Box 80.021, 3508 TA, Utrecht, The Netherlands
}

\section{A R T I C L E I N F O}

\section{Article history:}

Received 14 February 2015

Received in revised form 17 September 2015

Accepted 23 September 2015

Available online 28 November 2015

\begin{abstract}
A B S T R A C T
In this paper, we present four model-based scenarios exploring the potential for resource efficiency for energy, land and phosphorus use, and implications for resource depletion, climate change and biodiversity. The scenarios explored include technological improvements as well as structural changes in production systems and lifestyle changes. Many of such changes have long lead times, requiring up front and timely investments in infrastructure, innovative incentive structures and education. For simulating the scenarios we applied the IMAGE modelling framework, with a time horizon until 2050.

Our findings confirm a large potential for more efficient resource use: our (no new policies) baseline scenario shows a global increase, between 2010 and 2050, by $80 \%$ of primary energy use, $4 \%$ of arable land and $40 \%$ of phosphorus fertilisers. These numbers are reduced to $+25 \%$ (primary energy), $-9 \%$ (arable land) and $+9 \%$ (phosphorus) in the global resource efficiency scenario. Baseline developments and resource efficiency opportunities vary strikingly among regions, resources and sectors. Phosphorus use, for example, is expected to increase most on croplands in developing countries, whereas the largest potential for phosphorus use efficiency lies in the livestock sector and urban sewage treatment in industrialised countries. Consequently, while resource efficiency resonates well as a general notion in policy thinking, concrete policies need to be region-specific, resource-specific and sector-specific.

Efficiency efforts on one resource tend to contribute to efficient use of other resources and to benefit the environment. There are also trade-offs, however, and the synergies analysed do not make problemspecific policies redundant: in 2050, the global resource efficiency scenario presents higher phosphorus use and higher use of fossil fuels than in 2010; greenhouse gas emission targets are met by half; and biodiversity loss slows down but is not halted. Moreover, part of the efficiency gains in land and phosphorus use is sacrificed when this scenario is combined with ambitious climate policy, due to the substantial resource requirements for the deployment of bio-energy-albeit much less than in a scenario without more efficient resource use.
\end{abstract}

(c) 2015 Elsevier Ltd. All rights reserved.

\footnotetext{
* Corresponding author. Present address: European Commission, Joint Research Centre, Institute for Environment and Sustainability, Monitoring Agricultural Resources Unit-H04, Via Fermi 2749, TP 263, I-21027 Ispra (VA), Italy. Fax: +39033278 7033 .

E-mail addresses: maurits.van-den-berg@jrc.ec.europa.eu (M. van den Berg), kathleen.neumann@wur.nl (K. Neumann), detlef.vanvuuren@pbl.nl (D.P. van Vuuren), lex.bouwman@pbl.nl (A.F. Bouwman), tom.kram@pbl.nl (T. Kram), jan.bakkes@pbl.nl (J. Bakkes).
}

\section{Introduction}

Several international environmental assessments have shown that increases in the global population and further increases in economic activities form key drivers of a growing demand for food, water, energy and materials (MEA, 2005; OECD, 2012a; Van Vuuren et al., 2012). This demand leads to concerns with respect to resource scarcity and its multiple dimensions, including physical depletion, increasing exploitation and processing costs and geopolitical issues associated with the fact that many resources have a skewed geographical distribution, or are shared among nations as a common resource pool (Prins et al., 2011). In recent 
years, these concerns have led governments and international organisations to formulate strategies to foster sustainable resource use, such as OECD's Green Growth strategy (OECD, 2011, 2013); the EU flagship initiative for a resource-efficient Europe (EC, 2011); and FAO's Save and Grow policymaker's guide (FAO, 2011).

Efficiency improvement is often mentioned as an attractive strategy to address unsustainable resource use. Several studies have emphasized the potential for efficiency improvement, for energy (Barker et al., 2007; Cullen et al., 2011; De Beer, 1998; Graus et al., 2011; Interlaboratory Working Group, 1997), land (Godfray et al., 2010; Neumann et al., 2010; Koning et al., 2008; Smith et al., 2010; The Royal Society, 2009) and phosphorus (IAASTD, 2009; Ten Brink et al., 2010; Schröder et al., 2011). While studies have looked into the efficiency potential for these individual resources (see above), or looked at historical or future trends in the absence of new policies to increase resource efficiency (Schandl and West, 2010), very few studies have looked at the impacts of an integrated efficiency approach for multiple resources, the implications of such a strategy for resource depletion and environmental problems and the potential trade-offs among specific measures. Van Vuuren and Faber (2009),Van Vuuren et al. (2012, 2015), Hoff (2011) and Cambridge Econometrics et al. (2011) highlight the need for such a nexus approach and argue that the impacts of efficiency policies are also related to climate policy, which, therefore, should also be taken on board.

There are several ways to improve resource efficiency. This includes increasing production efficiency (e.g. less material use in construction, more "crop per drop", more efficient power plants); minimizing supply chain wastes and losses; increasing the consumption efficiency (e.g. energy efficient buildings, cars and household appliances); recycling or reusing waste materials; and changing consumption patterns (e.g. towards less meat intensive diets, or less long-haul holidays). Most policy strategies tend to emphasize technological innovations rather than changing consumer habits.

Given the current policy attention for resource efficiency and the scarcity of systematic analysis of comprehensive efficiency approaches, the objectives of this study are: (i) to identify current and future resource use trends for energy, land and phosphorus; (ii) to quantitatively explore the potential for enhanced resource efficiency also in relation to climate policy; and (iii) to identify synergies and/or trade-offs among resource efficiency measures for the different resources looked at. This is done in the form of a scenario study, at the scale of world regions and at the global scale, with a time horizon until 2050. The analysis provides a novel attempt at charting new territories for integrated assessment, focussing simultaneously on a set of three resources and firstorder-estimates of potential relationships between them. Emphasis is on obtaining insight in potential enhancements for this limited set of resources, their mutual interactions and implications for policy development, including relations with other policy fields such as climate change and biodiversity. For example, McCollum et al. (2011) emphasized the benefits of climate policy for energy security and air pollution control policies. Our analysis focuses on the physical dimension of resource efficiency and does not explicitly consider the economic, social or institutional consequences of the various strategies. It represents a quick scan of potentials, and consequently is not able to provide details per resource type. It does however, have significant policy-relevant general implications.

A more in-depth discussion of the scenarios analysed can be found in Van den Berg et al. (2011). That report considers five resource themes: energy, land, phosphorus, fresh water and fisheries. For the current article, we selected three, because of their distinct different nature, interlinkages, and prominence in the discourse on environmental sustainability and resource efficiency: (i) energy, based on the key role of fossil fuel combustion in climate change, as well as scarcity associated with fossil fuel reserves and their skewed geographical distribution; (ii) land, based on the discussion on competing claims for food, feed, fuel and forestry products; and the impacts of land use and land use change on terrestrial biodiversity and greenhouse gas emissions; and (iii) phosphorus, due to its key role in agricultural production for which

Table 1

Scenario assumptions regarding energy.

Baseline (BL) and Envisaged Policies (EP)

General

No new policies are introduced. In each region, energy efficiency improvement essentially follows the 2009 World Energy Outlook (IEA, 2009), based on a slow autonomous efficiency improvement and responses to price increase of fossil fuels

Industry

See general

Transport

See general

Residential

See general

Power generation

See general

Climate policy

BL: None

EP: Copenhagen pledges are implemented by introducing a regional carbon tax. The tax level is continued after 2020 [see Den Elzen et al. (2010) for a detailed description]
Global resource efficiency (RE) and Global resource efficiency \& climate policy (RECP)

Ambitious energy efficiency measures, including the use of bestavailable-technology. For the sectors not specifically covered below energy efficiency trends were calibrated to the energy efficient scenario, leading to a $20-30 \%$ reduction of energy use as described by Graus et al. (2011)

In steel and cement production, prescription of energy efficient, best-available technology to $17 \mathrm{GJ} / \mathrm{t}$ (see Roorda and Neelis (2006)). For other industry, a 30-40\% efficiency improvement was assumed based on the work of Graus et al. (2011)

Prescription of most efficiently newly built cars and planes and moderate shift to high-speed trains (away from air transport) based on Girod et al. (2012). See general for other modes of transport

Prescription of efficient technologies for heating, lighting and appliances. For temperate regions, for instance, energy use is assumed to drop to $0.2 \mathrm{GJ} / \mathrm{m}^{2}$ [see Daioglou et al. (2012) for a detailed description of the model]

Prescription of best available technology for fossil-fuel and bioenergy fueled power plants (depending on the region a 0-20\% improvement)

RE: Same as EP

RECP: Introduction of a carbon price in order to reach an emission profile consistent with the $2{ }^{\circ} \mathrm{C}$ target/RCP 2.6 emission pathway (Van Vuuren et al., 2011, 2010b) 
it is irreplaceable, and the limited resource base with reserves concentrated in a few countries.

The structure of the paper is as follows. First, we present a description of the scenarios analysed and the modelling framework applied. Second, we present and discuss the results for the three individual themes energy, land and phosphorus and consequences for climate and biodiversity. Next, we focus on the interactions among various resource efficiency interventions, including those with climate policy. Finally, we discuss our findings and present our conclusions in terms of their robustness, challenges for future research and policy relevance.

\section{Methodology}

\subsection{Scenarios}

Four scenarios are compared:

- The baseline (BL) scenario forms a reference that describes trends if no new policies were introduced. The baseline scenario used here is more-or-less equal to the baseline in the OECD Environmental Outlook 2012 (OECD, 2012a). It assumes that global population increases to around 9 billion people in 2050, and economic growth occurs in all regions with assumed gradual convergence trends. Resource efficiency improvements in this scenario are the implicit result of 'autonomous' technical progress.

- The envisaged policies scenario (EP) represents low-level climate policy commitments. It assumes, in addition to the baseline scenario, the implementation of the climate policy pledges (low level) made as part of the negotiations in Copenhagen and
Cancun. For the period after 2020 (for which no pledges were formulated), we assumed a constant carbon tax to mimic continuity at the same level of climate efforts. The modelling of the implementation of the pledges is based on Den Elzen et al. (2010).

- Global resource efficiency (RE) is a scenario in which we explore the potential impacts of ambitious resource efficiency strategies worldwide. Policies targeting climate change are restricted to those of the EP scenario.

- Global resource efficiency and climate policy (RECP) scenario explores the impacts of a combination of ambitious resource efficiency and climate policies aiming to achieve the so-called $2{ }^{\circ} \mathrm{C}$ objective. For the latter, we use a scenario similar to the RCP (Representative Concentration Pathway) 2.6, elaborated by Van Vuuren et al. (2011, 2010b). This scenario leads to radiative forcing of $2.6 \mathrm{~W} / \mathrm{m}^{2}$ by 2100 . Assumptions regarding resource efficiency are equal to those for the RE scenario.

For the two resource efficiency scenarios (RE, RECP), the objective was to describe ambitious improvements, at the frontier of what is technologically feasible and socially and politically conceivable. The assumptions made are provided in Table 1 for energy, Table 2 for land use, food, agriculture and forestry, and in Table 3 for phosphorus.

\subsection{Modelling framework}

For the analysis, we have used the IMAGE 2.4 integrated assessment framework (Bouwman et al., 2006), with a time horizon until 2050. This framework operates at a global grid of $0.5^{\circ} \times 0.5^{\circ}$ (about $55 \times 55 \mathrm{~km}$ at the equator) and was, for this

Table 2

Scenario assumptions regarding food, land use, agriculture and forestry.

\begin{tabular}{|c|c|c|}
\hline & Baseline (BL) and Envisaged Policies (EP) & $\begin{array}{l}\text { Global resource efficiency (RE) and Global resource } \\
\text { efficiency \& climate policy (RECP) }\end{array}$ \\
\hline Crop yield increase & $\begin{array}{l}\text { MAGE management factor adjusted by calibrating } \\
\text { IMAGE model yields against FAO yield projections (see } \\
\text { OECD, 2012a) }\end{array}$ & $\begin{array}{l}\text { Following Ten Brink et al. (2010): Baseline yield growth } \\
\text { rates are increased by 50\%, based on an assessment of } \\
\text { IAASTD ( } 2009 \text { ); but to a maximum increase of } 1.5 \% \text { per } \\
\text { year in OECD countries }\end{array}$ \\
\hline
\end{tabular}

Feed conversion efficiency

Supply chain waste and losses

Dietary preferences

Share of timber from plantation forests

Protected areas
Improvement according to historical trends of shifting from (1) roughage to feed concentrates, and (2) animal production from pastoral to intensive systems (Bouwman et al., 2005; Westhoek et al., 2011)

Continuation of current wastes and losses implicitly assumed

Share of animal products in diets increases in accordance with per capita income increase, following current trends (OECD, 2012a)

Increased production of forest products follows historical trend of exploitation from plantation/ natural forests (Brown, 2000)

Protected areas maintained at current level (globally ca 10 million $\mathrm{km}^{2}$ ) [Following Ten Brink et al. (2010), based on IUCN, UNEP (2006)]
Increase by $15 \%$ above the baseline level (pigs and poultry). Shift of ruminant production from pastoral to mixed systems is accelerated (Bouwman et al., 2013).

Following Ten Brink et al. (2010) (see also Stehfest et al. (2013)): reduction in waste and losses corresponding to $7 \%$ of total supplies from agriculture worldwide by 2050 . In the model this implies a $7 \%$ decrease in the amount of food required to meet the same level of nutrition

Following Ten Brink et al. (2010): in affluent regions, per capita consumption of animal products gradually decreases to a level of $50 \%$ above that suggested by Willett et al. (2001). This corresponds to a weekly intake per person of $105 \mathrm{~g}$ beef, $105 \mathrm{~g}$ pork, and $460 \mathrm{~g}$ poultry and eggs. Consumption of fish and dairy products follows the baseline. In regions with lower consumption of animal products, baseline assumptions are applied until these levels are reached

Following Ten Brink et al. (2010): forest plantations are expanded to meet about $50 \%$ of timber demand by 2050 . All selective logging is assumed to be based on Reduced Impact Logging (RIL)

Following Ten Brink et al. (2010): increase to 25 million $\mathrm{km}^{2}$, globally, covering a representative selection of the Earth's ecosystems, with a focus on areas with threatened and endemic species 
Table 3

Scenario assumptions regarding phosphorus.

Baseline (BL) and Envisaged Policies (EP)

Global resource efficiency (RE) and Global resource efficiency \& climate policy (RECP)

P-fertiliser use efficiency (FUE) FUE remains stable in industrialized countries with nearequilibrium $P$ fertilization. FUE gradually improves in countries with a current $P$ surplus (e.g. China, India), as soil residual $P$ pools have already been built up. $P$ use increases and FUE decreases in developing countries to build up soil $\mathrm{P}$ reserves

The relative extra yield increase in RE relative to that in $\mathrm{BL}$ is used as a basis. Higher yields in P surplus countries can be achieved with a higher efficiency. In P deficit countries, higher yields can be obtained by increasing fertilizer use. In industrialized countries and other countries with current P surplus (China, India) FUE is increased by half of the relative extra yield increase; in developing countries with current $P$ deficit, FUE is assumed to decrease by half of the additional relative yield compared to BL and EP

Animal P use efficiency

Manure integration
Excretion rates per animal are constant, excretion rates per unit of product decrease with increasing productivity

Manure is not considered in fertilizer use efficiency; the fraction manure not recycled in agriculture is constant

No recycling of human excreta
5\% (2030) and 10\% (2050) lower phosphorus excretion rates per animal for beef cattle, dairy cattle, pigs, sheep and goats and poultry to mimic the higher feed use efficiency compared to the BL

Manure that in BL ends outside the agricultural system (fuel use, manure lagoons) is recycled and used as fertilizer substitute $(100 \%$ of phosphorus is effectively available). This assumption is made only for countries where animal manure spreading is less than $25 \%$ of total phosphorus input in crop production systems. Other countries same as BL

Recycling of human phosphorus from urine and faeces from households with access to improved sanitation but with no sewage connection, and urine from households with a sewage connection. For both sources, recycling is assumed to include $25 \%$ of available phosphorus in 2030 and $50 \%$ in 2050. Data on sanitation and sewage based on Van Drecht et al. (2009)

For details on baseline and other assumptions, see Bouwman et al. (2009, 2013), and specific sources mentioned in the table cells.

study, applied at the level of 24 world regions. For presentation and discussion purposes, the results are aggregated to 7 geopolitical regions (Fig. 1): (i) EU+, (ii) Latin America and Caribbean, (iii) Russia region, (iv) China region, (v) Rest of OECD, (vi) Rest of Asia, and (vii) Africa.

Fig. 2 provides a schematic overview of the resources considered and the main linkages between them as included in the IMAGE framework. This is a strongly simplified representation. A more detailed graphical representation of the $\mathrm{P}$ model, for example, is given as Supplementary online material (Appendix A).
IMAGE can provide long-term projections for food and energy production. Both resource quantity and quality play key roles: for energy in terms of depletion of fossil fuels and good sites for renewable energy; for food production in terms of diminishing areas of (potentially) productive land. For both production systems, IMAGE also calculates the associated emissions of greenhouse gases and air pollutants to assess climate change. The latter is used, in combination with $\mathrm{CO}_{2}$ fertilisation effects, to calculate impacts on crop yields. The use of bio-energy in the energy system and food and feed production in agriculture are

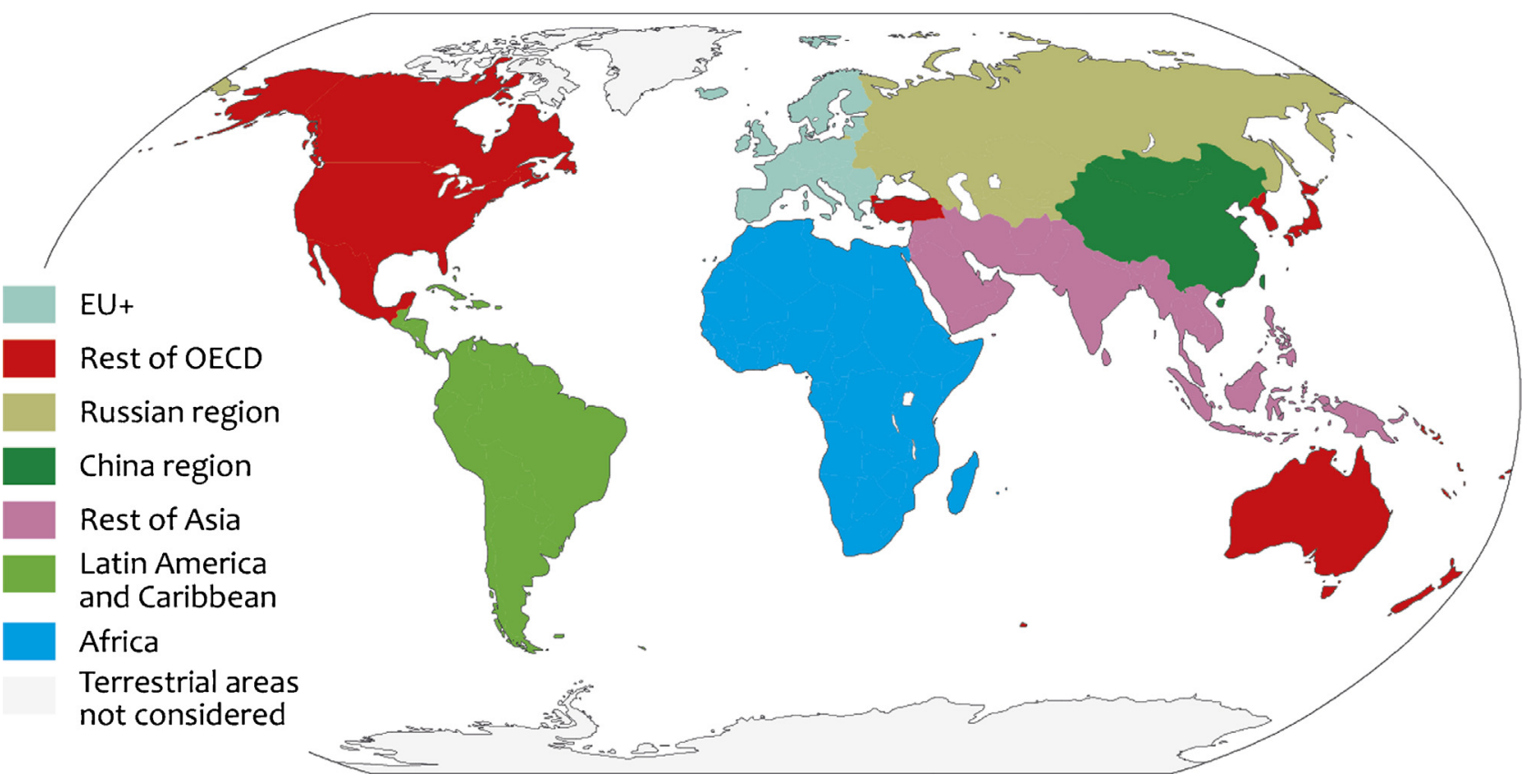

Fig. 1. Geo-political regions considered in the study. 


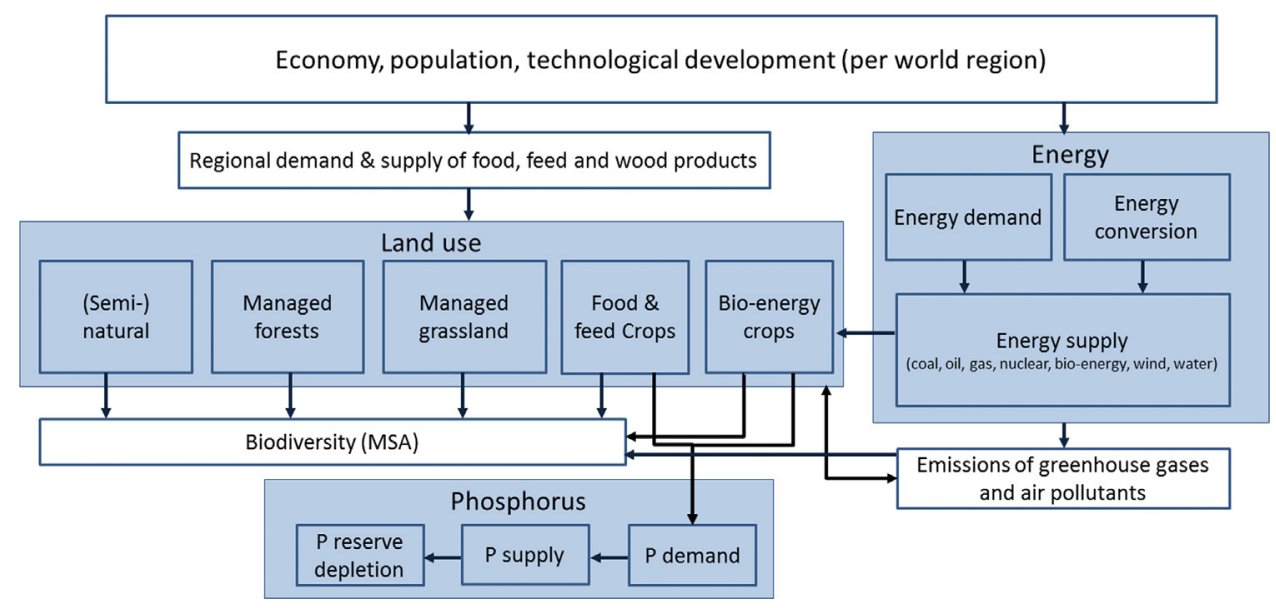

Fig. 2. Simplified representation of the modelling approach.

accounted for in the land use system, and impacts for terrestrial biodiversity are assessed. The same framework also accounts for the requirements of phosphorus for agricultural production, together with the impact on phosphorus resources. Key features of the model are the linkages between the different components that allow for assessing co-benefits and trade-offs. Below, we further elaborate the four key modules that are used in this study. More extensive descriptions of these modules are provided as supplementary on-line material.

The IMAGE global energy system model (TIMER) (Van Vuuren et al., 2007) describes the investments in, and use of different types of energy influenced by technology development and resource depletion. Inputs to the model are levels of economic activities and assumptions on technology development, preference levels and restrictions to fuel trade. The model projects future primary and final energy consumption by energy type, sector and region; and the associated greenhouse gas and air pollutant emissions such as ozone precursors and acidifying substances. The choice of different fuels is determined by their relative long-term costs, which, in turn, are driven by resource depletion and technology dynamics. Investment in more efficient technology is determined by comparing the relative costs of efficiency vis-à-vis the avoided expenses for fuels. Climate mitigation policies are represented in the model by putting an additional cost on greenhouse gas emitting technologies using a universal carbon-equivalent price.

The land \& climate module of the IMAGE model (Alcamo, 1994; Bouwman et al., 2006; Kram and Stehfest, 2012) computes expected land-use changes, related to the production of food crops and livestock, animal feed and fodder, bio-energy crops and timber at the level of 24 world regions. The spatial distribution of natural vegetation and crops is determined on the basis of the required production and productivity, on a spatial resolution of $0.5 \times 0.5$ degree. Food and feed crop and grass production is calculated with a simple crop model, based on climate conditions and soil characteristics and using assumptions on management and technology factors affecting yields. Subsequently, land-use types are allocated at grid cell level on the basis of rules concerning crop productivity, distance to existing agricultural land, distance to water bodies, and a random factor. IMAGE furthermore calculates emissions from land-use changes, natural ecosystems and agricultural production systems, and the exchange of carbon dioxide between terrestrial ecosystems and the atmosphere. This information is used to calculate climate change which is then fed back to calculate impacts on yields and natural vegetation.

The phosphorus demand and supply models (Bouwman et al., 2009, 2013; Van Vuuren et al., 2010a). Together, the demand and supply models for phosphorus describe its demand and the associated production and depletion of resources. Globally, demand is dominated by the agriculture sector, predominantly for fertilisers and to a minor extent for feed additives. The regionspecific demand for fertilisers is based on fertiliser use efficiency for the various crops considered in the IMAGE model and accounting for the availability of animal manure at the country level. P supply comes from the mining of rock phosphate or from recycling of manure or sewage. Rock phosphate mining is determined regionally, based on the quantity and quality of available resources and the costs of exploration and processing.

In the GLOBIO3 model (Alkemade et al., 2009), biodiversity loss is expressed as the reduction of mean species abundance (MSA), i.e. mean relative abundance compared to a natural, pristine situation. This is similar to for example the Biodiversity Intactness Index BII (Scholes and Biggs, 2005). A pristine ecosystem, by definition, has an MSA of $100 \%$. The MSA of a totally disturbed system is close to $0 \%$. Cultivated areas typically have an MSA between $10 \%$ and $30 \%$ (Alkemade et al., 2009). In GLOBIO, MSA is calculated as a function of information provided by IMAGE on environmental pressures, including land-cover change, land-use intensity, atmospheric nitrogen deposition, infrastructure development, fragmentation and climate change.

\section{Results}

\subsection{Energy}

In the baseline scenario, energy consumption is projected to increase by almost $80 \%$ between 2010 and 2050. Consistent with the trend over the last decades, most of this growth takes place in developing countries and emerging economies: In OECD countries, final annual energy use (i.e. energy use at end-use level) increases from $130 \mathrm{EJ}$ in 2010 to almost $150 \mathrm{EJ}$ by 2050 , whereas energy use in the rest of the world doubles over the same period. In per capita terms, this translates to almost constant consumption levels in OECD countries at 150-200 GJ per capita per year, and a strong increase in developing countries. In Asia, for example, energy consumption increases from around $20 \mathrm{GJ}$ per capita in 2010 to between 50 and $60 \mathrm{GJ}$ per capita by 2050. Primary energy consumption remains dominated by fossil fuels, but a shift occurs from oil to coal and natural gas as a result of depletion of conventional oil resources. The dependence on fossil fuels in total energy demand remains high (around 85\% in 2050). These results roughly conform the IEA World Energy Outlook (IEA, 2009) which was the main source for our baseline assumptions (Table 1 ). This 
projection is also consistent with the range of scenarios in more recent literature-such as those reviewed in the IPCC report (Clarke et al., 2014) and the Global Energy Assessment (GEA, 2012).

The envisaged policies scenario implies in 2050 about a 10\% decrease in the use of fossil fuels worldwide as compared to the baseline, mostly related to an increase in non-greenhouse gas emitting technologies. Obviously, most of this change takes place in regions with the most ambitious pledges (Europe). In most other regions, no change is observed.

The measures assumed in the global resource efficiency scenario (see Table 1 ) reduce total primary energy consumption in 2050 by about $30 \%$ as compared to the baseline scenario (from nearly $900 \mathrm{EJ} / \mathrm{yr}$ to slightly above $600 \mathrm{EJ} / \mathrm{yr}$ ). Most of this decrease refers to fossil fuels. This is consistent with specific studies estimating the potential for energy efficiency improvement in detail (Cullen et al., 2011; Graus et al., 2011; Jacobson and Delucchi, 2011). Jacobson and Delucchi (2011), for example, showed that by implementing the most advanced technical possibilities for energy efficiency, energy consumption could be reduced from 530 to $360 \mathrm{EJ}$ in 2030, i.e. a 35\% improvement in energy efficiency. Cullen et al. (2011) discussed ambitious energy improvement options in transport and finally, Graus et al. (2011) discussed the potential for energy efficiency in various sectors. These papers formed the basis for several of our assumptions focused on a more conventional technical potential, thus finding a similar reduction as identified here.

In the global resource efficiency and climate policy scenario, in addition to the efficiency policies, a carbon price is introduced that leads to significant changes in the energy mix (leading to a costeffective trajectory towards $2^{\circ} \mathrm{C}$ ) (Fig. 3, right; see also Section 3.4). However, compared to a "default strategy" to reach the $2{ }^{\circ} \mathrm{C}$ target [such as the RCP2.6 scenario using IMAGE of Van Vuuren et al. (2011) and most of the scenarios in the EMF 27 model comparison (Kriegler et al., 2014)], this scenario relies much more on reducing fossil fuel consumption by efficiency improvement, and much less on bio-energy, renewables, and carbon capture and storage (CCS).

In Table 4, the total cumulative use of fossil fuels in the 20102050 period is compared with current reserves and resource estimates (as used in the IMAGE-TIMER model, based on USGS estimates). It shows that, in the baseline scenario, cumulative consumption of oil and natural gas up to 2050 is of similar magnitude as current conventional reserve estimates, whereas the current estimate of the total resource base by far exceeds the fossil fuel used in any of the scenarios. The consumption of the different resource categories is accompanied by price increases and, in the next few decades, concentration of supply from a limited number of countries (in the longer term, the increasing use of unconventional resources stimulated by the price increase does somewhat compensate this effect). It should be noted that resource estimates are always beset with uncertainty, and that there is risk of the resource base being lower, in particular regarding the more speculative and unconventional resources.

Efficiency and climate policy reduce the consumption of fossil fuels, thus also reducing the ratio between cumulative use and resources estimates (Table 4); and oil prices are projected to increase much less in the global resource efficiency and climate policy scenario than in the baseline scenario. Lower prices also lead to less impact on price-induced energy efficiency, which implies that stronger policy measures are required than anticipated if such rebound effects are not accounted for. The strength of such rebound effects is not exactly known, however.

\subsection{Land}

Changes in population, and an income-driven shift towards higher per capita consumption, in particular of meat and milk in developing countries, are projected to lead to an increase in global food production of around 60\% between 2010 and 2050 in the baseline scenario. Consistent with historical trends, the scenario results indicate that most of this increase is met through an increase in agricultural productivity. Crop and animal productivity are projected to increase most in developing regions. These, however, also face the strongest agricultural expansion, if suitable land is still available, especially in Africa, where, in the baseline scenario, the area of crop land increases by $60 \%$ over this period. In other regions, in contrast, the agricultural area shows only slight changes or even presents a decline (Fig. 5). The net result is an increase by $4 \%$ of the global area of cropland, including the area for bio-energy crops.

In the envisaged policies scenario, all assumptions that are strictly land-related are the same as in the baseline (see Table 2). However, as a consequence of a different energy policy in this scenario an additional 5\% of crop land is used to accommodate the increase in bio-energy production.
Baseline

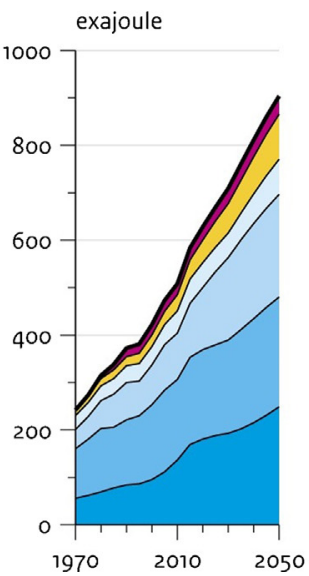

Envisaged Policies

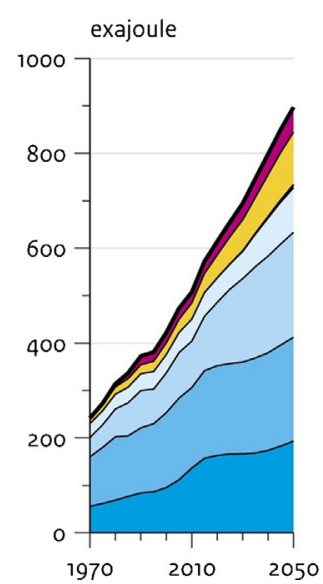

Global Resource Efficiency

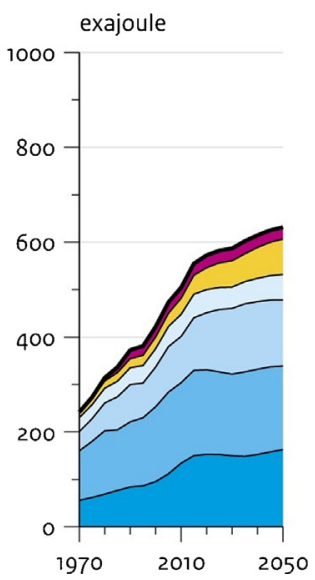

Global Resource Efficiency and Climate Policy

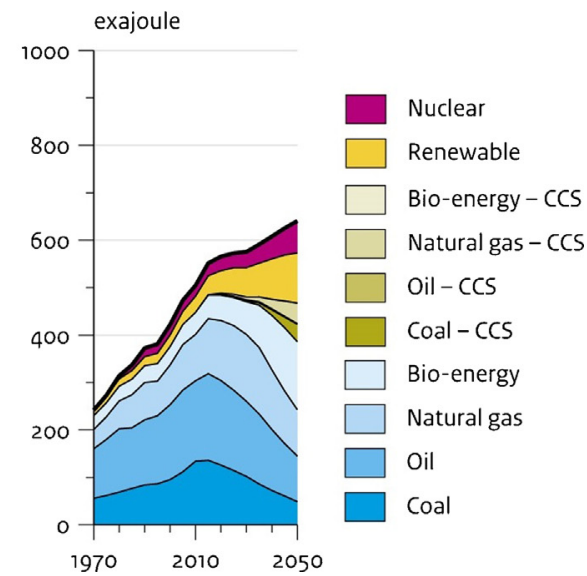

Fig. 3. Global primary energy use in the scenarios analysed. 
Table 4

Cumulative fossil fuel use and resource estimates (in ZJ).

\begin{tabular}{|c|c|c|c|c|c|c|c|}
\hline & \multicolumn{3}{|l|}{ Resource estimates } & \multicolumn{4}{|c|}{ Cumulative production $2010-2050$} \\
\hline & \multirow{2}{*}{$\begin{array}{l}\text { IMAGE } 2005 \\
\text { Reserves + resources }\end{array}$} & \multicolumn{2}{|c|}{$\begin{array}{l}\text { Global Energy Assessment (GEA, 2012) } \\
\text { current }\end{array}$} & \multirow[t]{2}{*}{ Baseline } & \multirow[t]{2}{*}{$\begin{array}{l}\text { Envisaged } \\
\text { policies }\end{array}$} & \multirow[t]{2}{*}{$\begin{array}{l}\text { Global resource } \\
\text { efficiency }\end{array}$} & \multirow{2}{*}{$\begin{array}{l}\text { Global resource } \\
\text { efficiency \& } \\
\text { climate policy }\end{array}$} \\
\hline & & Reserves & Resources & & & & \\
\hline Coal & 375.9 & 21.0 & 435.7 & 8.3 & 7.0 & 6.4 & 4.5 \\
\hline Conventional oil & 11.1 & 7.6 & 13.8 & & & & \\
\hline Unconventional oil & 15.1 & 3.8 & 15.1 & & & & \\
\hline Oil (total) & 26.2 & 11.4 & 28.9 & 8.2 & 7.6 & 7.1 & 6.1 \\
\hline Conventional gas & 11.6 & 7.1 & 16.0 & & & & \\
\hline Unconventional gas & 96.4 & 28.0 & 108.3 & & & & \\
\hline Gas (total) & 108.0 & 35.1 & 124.3 & 6.7 & 6.6 & 5.3 & 5.3 \\
\hline
\end{tabular}

The results for the global resource efficiency scenario illustrate that measures to increase yields and reduce losses can substantially reduce agricultural expansion. In this scenario, the cropland area in 2050 is smaller than in 2010 in all major world regions, except Africa, where expansion over this period is reduced by $30 \%$ in comparison to the baseline, and virtually halts after 2040. Grassland expansion is even more strongly reduced, as a result of the increased use of feed concentrates in this scenario. It should be noted that the measures to increase production efficiency in this scenario can also lead to lower food prices and thus more consumption (rebound effect), particularly in developing countries (Stehfest et al., 2013). In our resource efficiency scenario, however, in which the land related assumptions mainly follow the "combination of options" of Ten Brink et al. (2010), we assume a moderation of consumption patterns in affluent regions (Table 2). Overall, these counteracting effects result in very similar consumption globally as in the baseline.

Finally, agricultural land use in the global resource efficiency $\mathcal{E}$ climate policy scenario is affected as a consequence of an increased production of bio-energy crops (Figs. 4 and 5). This implies a significant increase in crop land, to a similar level as in the envisaged policies scenario. In terms of total agricultural area (crop land plus grassland), about half of the savings achieved with resource efficiency are used for increased bio-energy production. Nevertheless, as a consequence of the combination of energy efficiency (Section 3.1) with land efficiency, the land used for bioenergy production in this scenario is substantially less than in the “default" RCP 2.6 scenario using IMAGE (Van Vuuren et al., 2011). Bioenergy production in the latter is around the median of the range when compared to other models using the same climate target (Rose et al., 2014).

The yield improvements assumed in the baseline are based on FAO projections (Bruinsma, 2003; FAO, 2006). Such improvements and the implications regarding crop area outcomes also fall within the range of other studies [see e.g. Nelson et al. (2010)]. Nevertheless, achieving such improvements requires substantial capital investment as pointed out by Schmidhuber et al. (2009). While efficiency improvements have been about $1 \%$ per year in industrialized countries over the last five decades, they were much slower in many developing countries. Progress in resource efficiency in crop and livestock production as assumed in the global resource efficiency scenario would need a redoubling of efforts and investments in many developing countries.

\subsection{Phosphorus}

In the baseline scenario (Fig. 6), P fertiliser use is projected to increase rapidly, particularly in developing countries where food production is projected to increase strongest and which tend to have a $\mathrm{P}$ deficit today (consistent with other projections in the
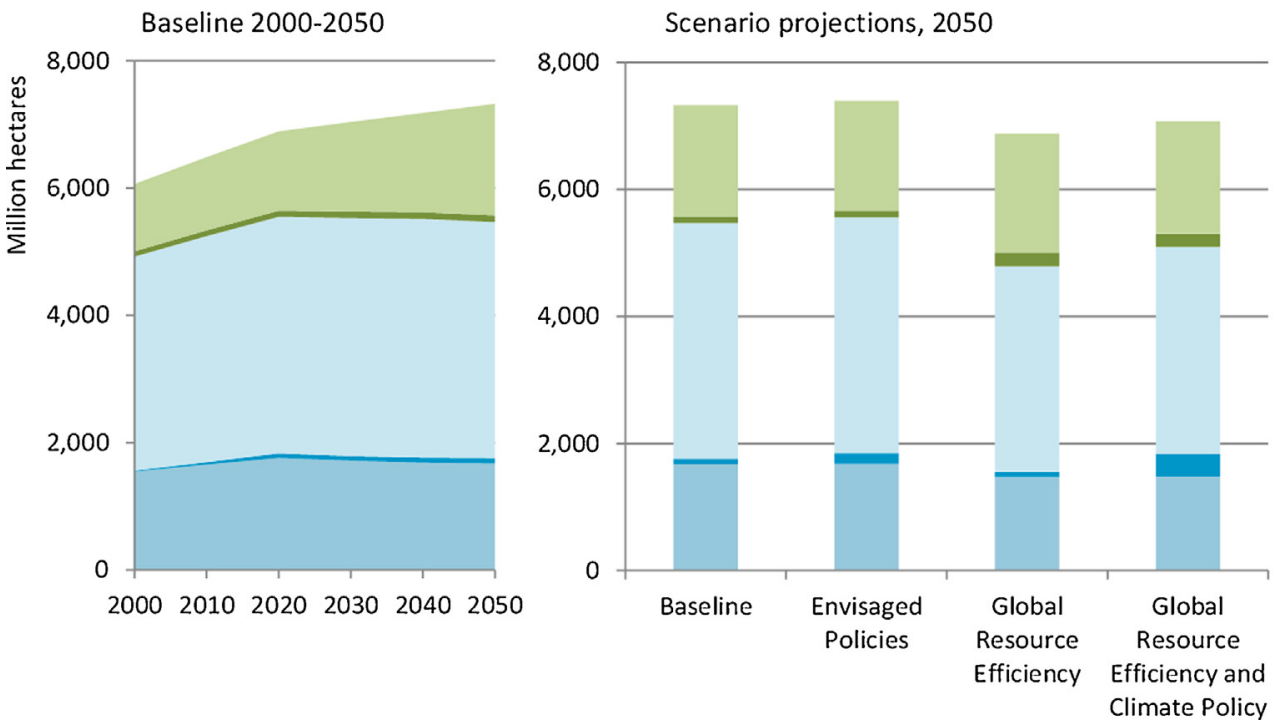

other exploited forest

plantation forest

grassland

bio-energy crops

(other) arable land

Fig. 4. Global land use in the scenarios analysed. 

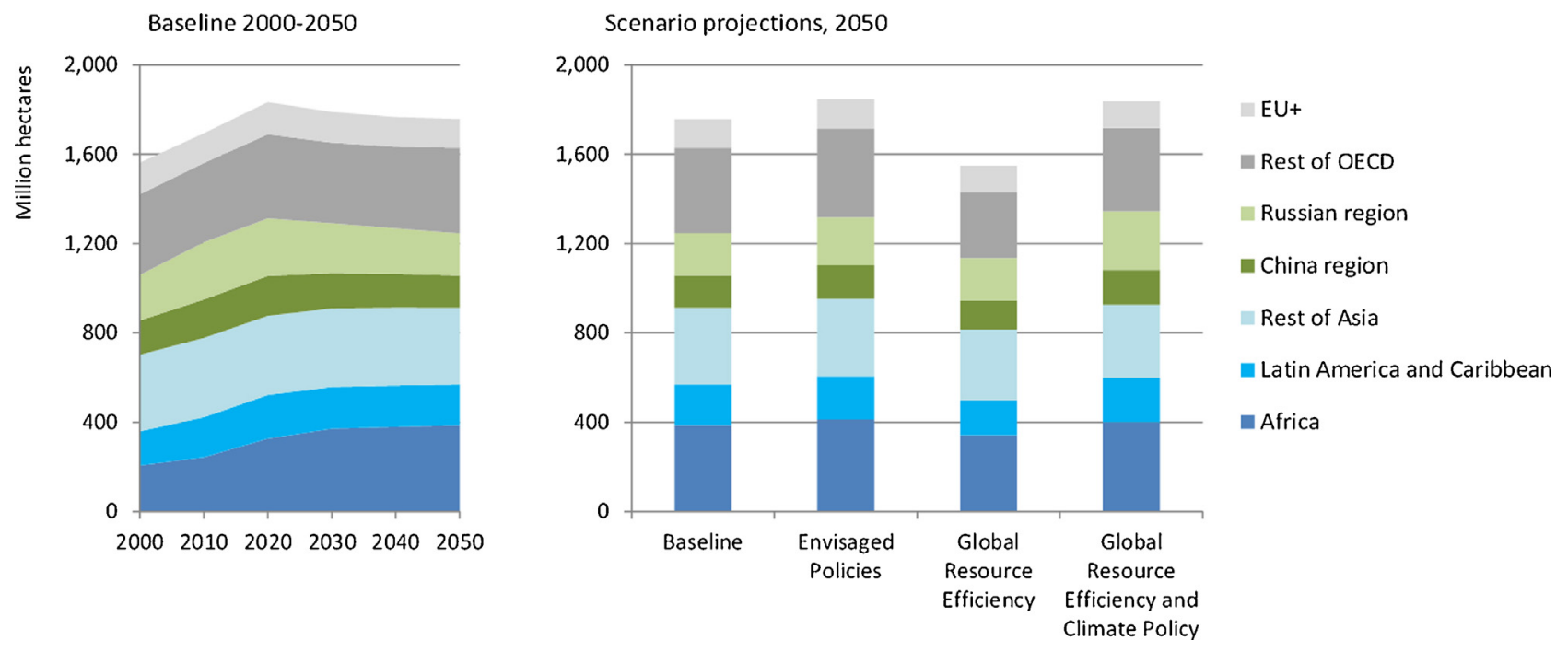

Fig. 5. Areas of arable land and bio-energy crops in the scenarios analysed.
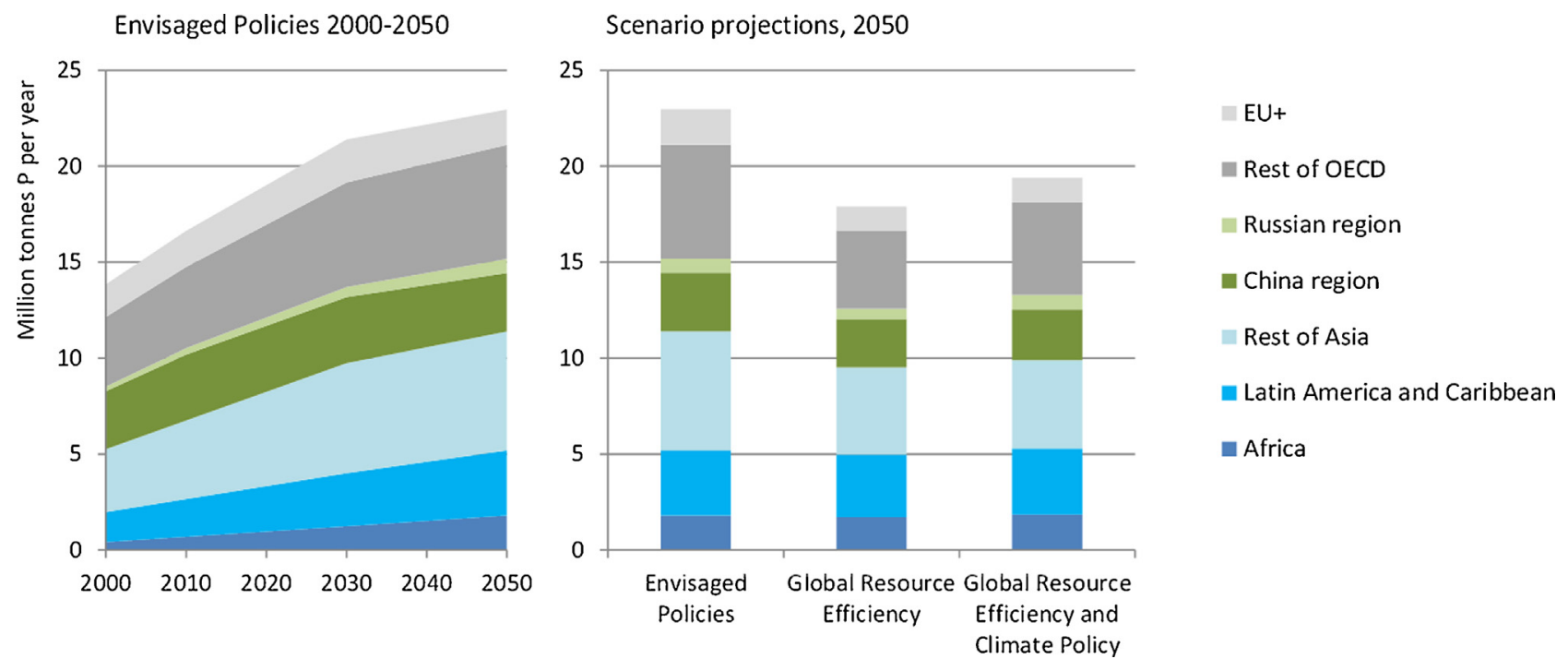

Fig. 6. Use of phosphorus fertilisers from primary resources in the scenarios analysed.

literature). In southern Africa, for example, $\mathrm{P}$ fertiliser use is projected to double between 2010 and 2050 . Globally, the increase of $\mathrm{P}$ fertiliser is about $40 \%$ over the same period, i.e. from 16.4 to 23 million tonnes.

In the global resource efficiency scenario, the use of $P$ fertiliser is affected by four mechanisms: (i) changes in agricultural production; (ii) effects of the efficiency measures for agriculture (crop and livestock) in general mentioned for the land theme; (iii) measures to enhance P-fertiliser use efficiency; and (iv) measures to recycle or reuse $P$ from animal manure and human excreta (see Table 3 ). An important limitation here is that the reduced demand for $P$ resulting from enhanced efficiency is partly counteracted by increased demand for $\mathrm{P}$ to achieve the agricultural productivity gains in this scenario (see the land theme). The net result is a reduction in the use of fertiliser $P$ from primary sources, to 18 million tonnes per year by 2050 ; a reduction of $22 \%$ compared to the baseline. Some studies have emphasized larger reduction potentials, in particular for high-income regions (Schröder et al., 2011). The resource efficiency gains in our study are smaller given the increases in $\mathrm{P}$ use in developing countries to increase agricultural productivity. Strategies that aim to recycle $\mathrm{P}$ (human excreta, animal manure) appear to be most effective. Hence, most of the P use efficiency gains are achieved in industrialised countries where current $\mathrm{P}$ use is already high and recycling is low. In developing countries, better integration is considered to be difficult because fertiliser use is minimal and animal manure already plays an important role in sustaining crop production.

In the global resource efficiency \& climate policy scenario, P use is greater than in the global resource efficiency scenario. This, again, is related to the production of bio-energy crops that require phosphorus and other nutrient inputs.

In recent years, several studies have focussed on the potential risk of $\mathrm{P}$ depletion. Some of the resulting publications indicated a risk of severe resource problems during the current century, or even within a few decades (Cordell et al., 2009; Mohr and Evans, 2013; Vaccari and Strigul, 2011). Others are more optimistic, as they also focus on resource estimates beyond conventional reserves (see also Van Vuuren et al., 2010a); a position which was strengthened by spectacular upward revision of the reserves in Morocco and Western Sahara in 2011 (USGS, 2011; Van 
Kauwenbergh et al., 2013) resulting in a fourfold increase of the global reserve estimate, albeit not free of controversy (Edixhoven et al., 2014; Scholz and Wellmer, 2015). Our results, combined with the approach and assumptions of Van Vuuren et al. (2010a) to translate these to phosphate rock extraction, suggest that about $20 \%$ of conventional resources will be depleted by 2050 , even without accounting for the USGS (2011) upward revision. This implies that there are no indications of short- to medium-term depletion at this level. It should be noted, however, that as highquality phosphate resources are ultimately depletable, efficient use will prolong the ability to use these resources in the long term. Moreover, depletion of low-cost and high-grade resources will have consequences for production trends and costs, and key agricultural production regions, such as the EU, Latin America, southern Asia and eventually also North America will increasingly depend on P supply from a single region in northern Africa.

\subsection{Consequences for climate and biodiversity}

As indicated in the introduction, there are important linkages between policies aimed at resource efficiency and key environmental problems. Here, we concentrate on effects on climate change and terrestrial biodiversity loss.

\subsubsection{Climate change}

In the baseline scenario, greenhouse gas emissions are projected to increase substantially (Fig. 7). As a consequence, around 2050 the world would follow an emission trajectory that is leading to about $4{ }^{\circ} \mathrm{C}$ global mean temperature increase in 2100 (as projected by IMAGE). The efficiency measures included in the global resource efficiency scenario lead to a substantial reduction of emissions (around 30\% compared to baseline). Most of this reduction is a result of the efficiency improvements in the energy sector, but also land-use related emissions would be reduced, from 3.3 to $1.7 \mathrm{GtC}$-eq. As a consequence, the expected increase in global mean temperature at the end of this century is reduced from $4{ }^{\circ} \mathrm{C}$ in the baseline to around $3^{\circ} \mathrm{C}$. By also introducing climate policy, in the global resource efficiency $\mathcal{E}$ climate policy scenario, emissions are further reduced to a level consistent with the $2{ }^{\circ} \mathrm{C}$ target. This corresponds to an emission reduction in 2050 of about $50 \%$ compared to 2010 . About $45 \%$ of this reduction can be attributed to efficiency improvements included in the global resource efficiency scenario.

\subsubsection{Biodiversity}

For biodiversity, the baseline scenario projects a decline in terms of the global mean original species abundance (MSA), from $67 \%$ in 2010 to $60 \%$ in 2050 . The main drivers in developing countries are the expansion of agricultural area and climate change. In other world regions, alongside climate change, continued biodiversity decline is mainly driven by the ongoing pressure from forest exploitation and the effects of fragmentation, infrastructure and encroachment, and reactive nitrogen emissions. At the global level, the envisaged policies scenario shows a marginal net improvement in MSA compared to the baseline. In some regions, however, the modest benefits of climate change mitigation in this scenario are outweighed by the extra pressure on land needed for the projected increase in bio-energy production. The global resource efficiency scenario presents a more substantial and more uniform reduction of biodiversity loss (compared to the baseline). The effect is much less, however, than expected on the basis of preliminary 0 -order calculations, as (according to our model results) in these scenarios forest exploitation would continue to exert a high pressure on biodiversity where agricultural expansion has ceased and forestry products are no longer available as a 'by-product' of land conversion. Several other pressures on biodiversity are also expected to increase despite the reduction of the key land-use and climate drivers. First of all, with respect to climate change, the projected global mean temperature is higher in this ambitious scenario than it is today. The pressures of infrastructure development and fragmentation also increase in all scenarios (see Ten Brink et al. (2010) for extensive discussion). The increased production of bio-energy crops according to the global resource efficiency $\mathcal{E}$ climate policy scenario puts an additional constraint on biodiversity which is not fully compensated by the additional climate mitigation effects of this scenario before the time horizon

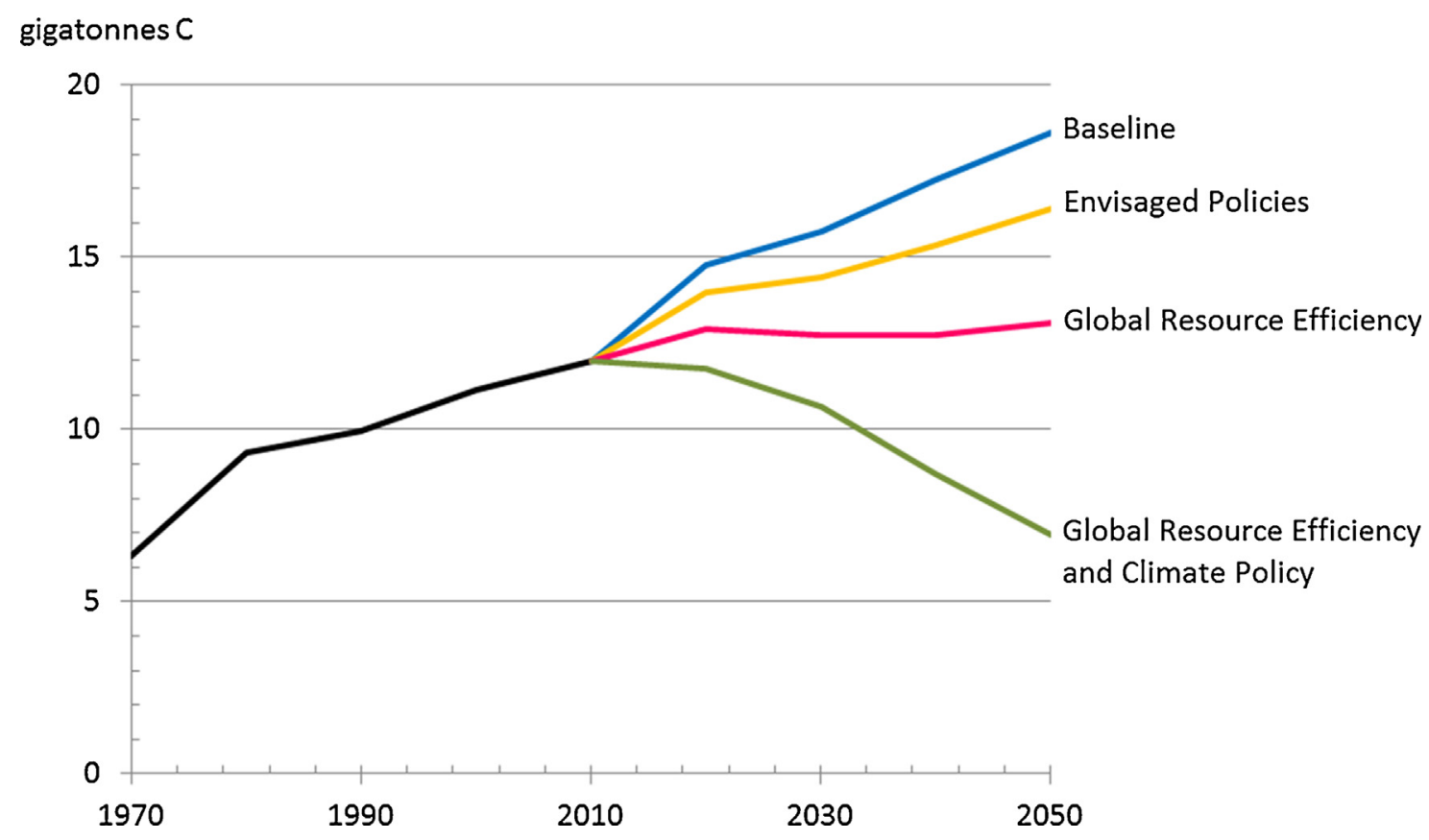

Fig. 7. Global greenhouse gas emissions in the scenarios analysed. 


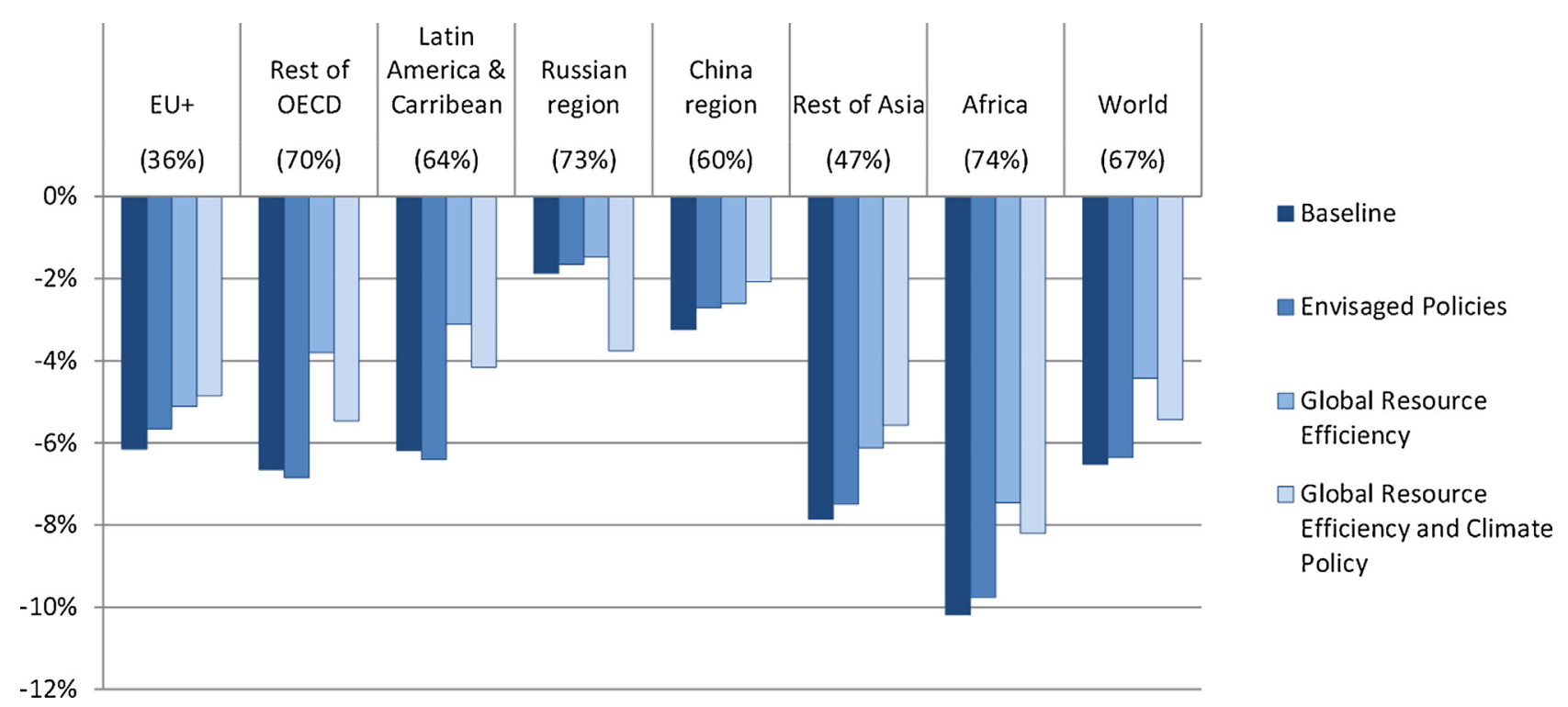

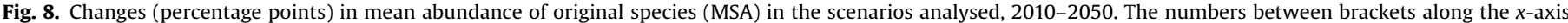
represent the MSA values calculated for 2010 . A pristine ecosystem, by definition, has an MSA of $100 \%$; the MSA of a totally disturbed system is close to $0 \%$.

applied in this study (Fig. 8). Exceptions are regions with little bioenergy crop production, such as EU+, which benefits from the climate mitigation effects of the deployment of bio-energy on biodiversity, while most of its own bio-energy demands are satisfied by imports.

\subsection{Interactions between interventions}

An overview of interactions between resource efficiency interventions targeting different resources, as well as between such interventions and climate policy is provided in Table 5. Some of the interactions are fairly obvious, such as improved energy efficiency helping to mitigate climate change, helping to slow down biodiversity loss; or the beneficial effects of soil conservation on land use efficiency, biodiversity and P use efficiency. Others are more complex, such as the dominantly positive interactions between climate policies and strategies to improve land use efficiency by improving crop yields and livestock husbandry and/or reducing the consumption of ruminant livestock products (as extensively discussed by Westhoek et al. (2011)). Negative interactions noted in Table 5 are rather complex:

- Total fertiliser P requirements to accelerate crop yield increases in developing countries-as part of a land use efficiency strategyare higher than in the baseline with lower yields, albeit with larger areas of crop land. We note that this is a temporary phenomenon: In the resource efficiency scenarios, eventually fertiliser $\mathrm{P}$ use can be reduced once soil $\mathrm{P}$ reserves have built up.

- Additional land and P requirements for bio-energy crops in a scenario with ambitious climate change policies.

- Additional energy requirements to process and/or transport manure (including from sewage) from surplus regions to regions with a deficit. Such energy requirements are not accounted for by the models used.

Overall, however, positive interactions appear to outweigh the negative ones, suggesting that climate policies and resource efficiency measures targeting several resources combined can be more effective than the sum of isolated measures.

\section{Discussion and conclusions}

\subsection{Methodological aspects and challenges for further research}

In this study, we focused on obtaining an overall impression of the potential for resource use efficiency, interactions across different resources and with other policy issues such as climate change and biodiversity. The method has limitations that might be addressed in subsequent research. First, in this study a number of key resources were analysed but other resources have not been looked into yet. Second, in each scenario, all three resources are targeted simultaneously. This makes the number of scenario projections manageable, but it also limits the potential for attributing observed outcomes to individual resources and/or instruments. Third, the analysis focused on the physical dimension of resource efficiency and only marginally touches upon the economic and policy barriers to be taken. Economic impact of investment strategies and subsidies on resource efficiency was not analysed, neither the impacts of resource efficiency improvements on GDP. Efficiency improvement tends to reduce prices of resources and/or of resource benefits, leading to rebound effects in demand, which, in some cases, may potentially even exceed baseline levels (Polimeni et al., 2007; van den Bergh, 2011). Additional policies may therefore be needed to prevent such impacts. Finally, the biophysical modelling also has its limitations, partly due to the global level of the analysis, partly due to an incomplete understanding of all the factors involved and their interactions.

Consequently, we can identify a couple of challenges for future research. First, explicit inclusion of economic aspects could provide a more realistic picture on both the profitability and feasibility of resource efficiency improvements. This also concerns a more explicit analysis of rebound effects. Other potential barriers for implementing resource efficiency measures could also be included, such as institutional, political, social, cultural and/or marketintegration issues. Third, obviously, the resources included in our analysis are not complete and neither are the feedbacks. Inclusion of additional feedbacks as well as of additional resources may be worthwhile to achieve a more comprehensive picture of both the 
Table 5

Interactions between resource efficiency interventions.

\begin{tabular}{|c|c|c|c|c|}
\hline $\begin{array}{l}\text { Co-effects on } \\
\text { Target of } \\
\text { interventions }\end{array}$ & Energy & Land / terrestrial biodiversity & Phosphorus & Climate-change mitigation \\
\hline Energy & & $\begin{array}{l}\text { Mitigation of climate change } \\
\text { Less nitrogen deposition } \\
\text { associated with fossil fuel } \\
\text { combustion } \\
\text { Less other associated forms of } \\
\text { pollution* }\end{array}$ & little or none, globally & $\begin{array}{l}\text { less greenhouse gas } \\
\text { emissions from fossil fuels }\end{array}$ \\
\hline $\begin{array}{l}\text { Land / terrestrial } \\
\text { biodiversity }\end{array}$ & $\begin{array}{l}\text { Less field operations (tillage, } \\
\text { harvesting etc.) }\end{array}$ & & $\begin{array}{l}\text { Avoidance of P loss through } \\
\text { erosion due to soil } \\
\text { conservation measures to } \\
\text { maintain/enhance productivity* } \\
\text { more fertiliser phosphorus } \\
\text { needed in developing } \\
\text { countries }\end{array}$ & $\begin{array}{l}\text { Less } \mathrm{CH}_{4} \text { emissions due to } \\
\text { improved animal feed* } \\
\text { Less } \mathrm{CO}_{2} \text { emissions from land } \\
\text { conversion and field } \\
\text { operations } \\
\text { Less } \mathrm{CH}_{4} \text { emissions from } \\
\text { ruminant livestock }\end{array}$ \\
\hline Phosphorus & $\begin{array}{l}\text { Manure \& sewage processing } \\
\text { and transport from surplus } \\
\text { regions to deficit regions* }\end{array}$ & $\begin{array}{l}\text { Soil quality benefits from soil } \\
\text { conservation measures to } \\
\text { avoid P loss* }\end{array}$ & & little or none, globally \\
\hline \multirow[t]{3}{*}{ Climate policy } & $\begin{array}{l}\text { Climate policy incentive for } \\
\text { energy efficiency }\end{array}$ & $\begin{array}{l}\text { Less impact of climate change } \\
\text { on biodiversity }\end{array}$ & \multirow{3}{*}{$\begin{array}{l}\text { Additional phosphorus } \\
\text { requirements for bio-energy } \\
\text { crops }\end{array}$} & \\
\hline & \multirow[t]{2}{*}{$\begin{array}{l}\text { Promotion of (subsidised) } \\
\text { renewables* }\end{array}$} & $\begin{array}{l}\text { Effects of climate change on } \\
\text { crop yields }\end{array}$ & & \\
\hline & & $\begin{array}{l}\text { Additional land required for } \\
\text { bio-energy crops }\end{array}$ & & \\
\hline \multicolumn{5}{|c|}{$\begin{array}{l}\text { Texts marked with * refer to } \infty \text {-effects that are not addressed by the models used in this study. } \\
\text { Types of co-effects: } \square \text { positive; } \square \text { mixed positive \& negative; } \square \text { negative }\end{array}$} \\
\hline
\end{tabular}

current potential for resource efficiency improvements as well as projections of future resource use. Additional scenarios with different assumptions can easily be run within the same modelling framework to better understand the effects of specific measures and different combinations of measures.

Furthermore, for the implementation of the two resource efficiency scenarios (RE, RECP) we made an effort to describe a frontier of ambitious improvements which are technologically feasible and socially and politically conceivable, harmonized across different subject areas. Obviously, some degree of subjectivity cannot be avoided here. The study should therefore be seen as a first quantified exploration of trajectories of resource use and of how resource efficiency efforts compare to gains derived thereof. Future studies could explore different or more refined sets of assumptions on resource efficiency improvement.

Baseline assumptions, obviously, will also influence the quantitative outcomes of the study. The baseline scenario of this study was published in 2012. The long-term trends in this baseline scenario are still representative of a median "business-as-usual" style scenarios, so using a more recently developed baseline projection (e.g. of energy use) would not change the essence of the findings.

\subsection{Policy implications and conclusions}

Despite the above-mentioned needs for further research, which would make this type of studies more suitable to evaluate specific policy measures-individually or combined-to enhance resource efficiency, the results based on the limited integrated approach presented here on energy, land use and phosphorus and their inter-linkages with climate policy and biodiversity do have significant policy implications. In the policy discussions in preparation of the EU flagship initiative for a resource-efficient Europe (EC, 2011), interim results of our analysis allegedly facilitated the positioning of resource efficiency as a Commissionwide idea that appealed to the interests and viewpoints of a wide range of actors, beyond the conventional environment portfolio. Four main conclusions can be drawn concerning policy implications.

First, our findings confirm that significant potential for resource efficiency exists. The potential is large in terms of what is physically possible and in terms of connecting resource policy with climate policy. This notion lies at the basis of the extensive policy attention given to the subject.

Specifically, the baseline projections show a global increase by $80 \%$ of primary energy use, $4 \%$ of arable land and $40 \%$ of fertiliser $P$ consumption between 2010 and 2050. In the global resource efficiency scenario, the scenario targeting the most ambitious resource efficiency measures without additional climate policies, over the same period, these numbers are reduced to $+25 \%$ (primary energy), $-9 \%$ (arable land) and $+9 \%$ (P fertilisers). Total global $\mathrm{P}$ use from primary sources would almost stabilise if, in addition, $\mathrm{P}$ in detergents is phased out. These potential improvements can substantially reduce risks with respect to resource sustainability 
and environmental degradation. Thus, the notion of resource efficiency is potentially attractive for leaders in policy, business and environment, as a positive and significant proposition.

Second, this study illustrates that resource use trends and efficiency mechanisms vary strongly across regions and across resources. This relates to the type of effects, the synergies and the trade-offs. For example, in the case of phosphorus our results show that resource use is expected to increase most in developing countries, whereas the largest potential for resource efficiency lies in industrialised countries. These striking regional differences are superimposed on the earlier mentioned geo-political dimension of resource scarcity (Prins et al., 2011). Such multiplicity is reflected in the variety in societal opinions on what aspect of resource efficiency should be formalized in policy indicators (Jacob et al., 2014).

Consequently, while improving resource efficiency as a general notion appears to resonate well in policy thinking in many regions and across many sectors (Dobbs et al., 2011; OECD, 2012b; UNEP, 2012), concrete policy arrangements on efficiency strategies need to be resource-specific and sector-specific (Kaiser et al., 2012). Thus, resource efficiency defines a good arena to bring to bear specific strengths of industry and governments (as well as of conservationists)-assuming they can broadly agree on ambition levels.

Third, the scope to reduce the consumption of one resource is often linked to what happens to another resource. Many of these linkages lead to synergies. For example, efficiency improvement in the food chain not only leads to reduced biodiversity loss but also to less greenhouse gas emissions and phosphorus demand, as well as improved efficiency in the energy system. However, there are also trade-offs, as in increased fertiliser requirements to sustain improved crop productivity and thus land efficiency. Likewise, there is a trade-off between increase of bio-energy production - as an instrument of climate change mitigation - and the effects this has on phosphorus demand and biodiversity.

Thus, international environmental policy could clearly benefit from an integrated resource efficiency approach such as presented in this study. Well-balanced policies could be designed to benefit as much as possible from synergism between measures in different domains while attempting to minimize negative effects. Such combined policies might also address potential rebound effects. Taxation of greenhouse gases can, for example, reduce the consequences of downward impacts on prices as a result of efficiency policies. Other examples show how combinations of policies (in multiple domains and levels) to discourage natural land conversion on one hand and to encourage more efficient use of existing agricultural land on the other, can contribute to biodiversity, food security and climate goals concurrently (Nepstad et al., 2013, 2014). In terms of analytical support for resource efficiency policies, there is a notable difference between, on the one hand, integrated diagnostics underpinning strategic policy making and, on the other hand, resource-specific, process-specific analyses informing decisions on, for example, renewing industrial plants or introducing specific taxes.

Fourth, the synergies analysed do not make problemspecific policies redundant. For example, under the most ambitious resource efficiency measures, the projected global greenhouse gas emissions savings in 2050 are 12 Gton C-eq as compared to the baseline scenario. While efficiency measures reduce greenhouse gas emissions, they are insufficient to meet the internationally agreed climate targets. In other words, for accomplishing international climate targets also supply side changes, including increasing shares of renewable energy carriers are required, as in our RECP scenario. As another example, more efficient use of land resources, as shown in this study mainly through improved agricultural practices, contributes to slowing down biodiversity loss. This alleviates the problem but does not fully resolve it. On balance, the global resource efficiency scenario (RE) in 2050 presents higher P use and higher use of fossil fuels than in 2010; greenhouse gas emission targets are not met; and biodiversity loss slows down but is not halted. Therefore, while the efficiency gains analysed can substantially reduce risks with respect to resource sustainability and environmental degradation, they are, by themselves, insufficient to fully resolve these issues. Thus, a drive towards resource efficiency policies would not compete with, for example, climate policy. Rather, it provides a logic and vocabulary for new alliances to jointly address great challenges.

In appreciating these findings, it is important to bear in mind that the resource efficiency improvements modelled here are anything but marginal or effortless. They are technically possible, but ambitious, with annual efficiency improvements being realized much faster than historical improvements, and consistently so for decades. It is important to note that many of the projected changes have long lead times, requiring up front and timely investments in for example infrastructure, innovative incentive structures and education. In other words, the time lines shown are not hop-on hop-off routes to a target.

\section{Acknowledgements}

We acknowledge the support of the European Commission for financing the project that formed the basis of this paper (Negotiated Procedure F.1/2010/Ref $\mathrm{N}^{\circ} 1$ ARES (2010) 818226), and in particular Mihai Tomescu and his colleagues from DG ENV and DG CLIMA for their constructive comments; the OECD for permission to use the preliminary baseline of the 2012 OECD Environmental Outlook; Wina Crijns-Graus (Utrecht University) for providing access to the raw data of her PhD thesis on energy efficiency, and all PBL colleagues who contributed to this work: Bastien Girod, Sebastiaan Deetman, Jasper van Vliet, Bas van Ruijven and Michel den Elzen (energy efficiency and greenhouse gas emissions calculations), Michel Jeuken and Mark van Oorschot (biodiversity), Kees Klein Goldewijk (land use); Jan de Ruiter (Fig. 1).

\section{Appendix A. Supplementary data}

Supplementary data associated with this article can be found, in the online version, at http://dx.doi.org/10.1016/j. gloenvcha.2015.09.016.

\section{References}

Alcamo, J., 1994. IMAGE 2.0: Integrated Modeling of Global Change. Kluwer Academic Publishers, Dordrecht, pp. p. 318.

Alkemade, R., van Oorschot, M., Miles, L., Nellemann, C., Bakkenes, M., ten Brink, B. 2009. GLOBIO3: A framework to investigate options for reducing global terrestrial biodiversity loss. Ecosystems 12, 374-390.

Barker, T., Ekins, P., Foxon, T., 2007. Macroeconomic effects of efficiency policies for energy-intensive industries: the case of the UK Climate Change Agreements, 2000-2010. Energy Econ. 29, 760-778.

Bouwman, A.F., Van der Hoek, K.W., Eickhout, B., Soenario, I., 2005. Exploring changes in world ruminant production systems. Agric. Syst. 84, 121-153.

Bouwman, A.F., Kram, T., Klein Goldewijk, K., 2006. Integrated Modelling of Global Environmental Change. An Overview of IMAGE 2.4. Netherlands Environmental Assessment Agency, Bilthoven p. 228 Publication 500110002/2006.

Bouwman, A.F. Beusen, A.H.W., Billen, G., 2009. Human alteration of the global nitrogen and phosphorus soil balances for the period 1970-2050. Global Biogeochem. Cycles 23, GB0A04.

Bouwman, A.F., Klein Goldewijk, K., Van Der Hoek, K.W., Beusen, A.H.W., Van Vuuren, D.P., Willems, J., Rufino, M.C., Stehfest, E., 2013. Exploring global changes in nitrogen and phosphorus cycles in agriculture induced by livestock production over the $1900-2050$ period. Proc. Natl. Acad. Sci. 110, 20882-20887.

Brown, C., 2000. The Global Outlook for Future Wood Supply from Forest Plantations. FAO Working Paper, Rome. 
Bruinsma, J., 2003. World Agriculture: Towards 2015/2030. An FAO perspective. Earthscan, London \& FAO, Rome.

Cambridge Econometrics, Wuppertal Institute, S.E.R.I., 2011. Sustainability Scenarios for a Resource Efficient Europe. Final Report for the European Commission (DG Environment), Cambridge, pp. 84.

Clarke, L., Jiang, K., Akimoto, K., Babiker, M., Blanford, G., Fisher-Vanden, K. Hourcade, J.C., Krey, V., Kriegler, E., Löschel, A., McCollum, D., Paltsev, S., Rose, S , Shukla, P.R., Tavoni, M., van der Zwaan, B., van Vuuren, D.P., 2014. Assessing transformation pathways. In: Edenhofer, O., Pichs-Madruga, R., Sokona, Y., Farahani, E., Kadner, S., Seyboth, K., Adler, A., Baum, I., Brunner, S., Eickemeier, P., Kriemann, B., Savolainen, J., Schlömer, S., von Stechow, C.Z., wickel, T., Minx, J.C. (Eds.), IPCC, 2014. Climate Change 2014: Mitigation of climate change. Contribution of Working Group III to the Fifth Assessment Report of the Intergovernmental Panel on Climate Change. Cambridge University Press, Cambridge (UK) and New York (USA).

Cordell, D., Drangert, J.-O., White, S., 2009. The story of phosphorus: global food security and food for thought. Global Environ. Change 19, 292-305.

Cullen, J.M., Allwood, J.M., Borgstein, E.H., 2011. Reducing energy demand: what are the practical limits? Environ. Sci. Technol. 45, 1711-1718.

Daioglou, V., van Ruijven, B.J., van Vuuren, D.P., 2012. Model projections for household energy use in developing countries. Energy 37, 601-615.

De Beer, J., 1998. Potential for Industrial Energy Efficiency Improvement in the Long Term, Department of Science. Technology and Society, Utrecht University.

Den Elzen, M.G.J., Hof, A.F., Mendoza, A.F., Beltran, M.A., Roelfsema, M., van Ruijven, B.J., van Vliet, J., van Vuuren, D.P., Höhne, N., Moltmann, S., 2010. Evaluation of Copenhagen Accord: Chances and risks of the 2C climate goal. PBL Netherlands Environmental Assessment Agency, Bilthoven.

Dobbs, R., Oppenheim, J., Thompson, F., Brinkman, M., Zornes, M., 2011. Resource Revolution: Meeting the World's Energy, Materials, Food, and Water Needs. McKinsey Global Institute.

EC, 2011. A resource-efficient Europe-flagship initiative under the Europe 2020 strategy. Communication from the Commission to the European Parliament, the Council, the Economic and Social Committee and the Committee of the Regions. Commission of the European Communities, Brussels.

Edixhoven, J.D., Gupta, J., Savenije, H.H.G., 2014. Recent revisions of phosphate rock reserves and resources: a critique. Earth Syst. Dyn. 5, 491-507.

FAO, 2006. World Agriculture: Towards 2030/. Interim Report. Prosp Ects for Food, Nutrition, Agriculture and Major Commodity Groups. Global Perspectives Studies Unit. Food and Agriculture Organization of the United Nations, Rome p. 71.

FAO, 2011. Save and Grow. A Policymaker's Guide to the Sustainable Intensification of Smallholder Crop Production. Food and Agriculture Organization of the United Nations, Rome.

GEA, 2012. Global Energy Assessment-Toward a Sustainable Future, Cambridge University Press, Cambridge, UK and New York, NY, USA and the International Institute for Applied Systems Analysis, Laxenburg, Austria.

Girod, B., van Vuuren, D.P., Deetman, S., 2012. Global travel within the $2{ }^{\circ} \mathrm{C}$ climate target. Energy Policy 45, 152-166.

Godfray, H.C.J., Beddington, J.R., Crute, I.R., Haddad, L., Lawrence, D., Muir, J.F., Pretty, J., Robinson, S., Thomas, S.M., Toulmin, C., 2010. Food security: the challenge of feeding 9 billion people. Science 327, 812-818.

Graus, W., Blomen, E., Worrell, E., 2011. Global energy efficiency improvement in the long term: a demand- and supply-side perspective. Energy Efficiency 4, 435463.

Hoff, H., 2011. Understanding the Nexus. Background paper for the Bonn 2011 Nexus Conference: The Water, Energy and Food Security Nexus. Stockholm Environment Institute, Stockholm p. 51.

IAASTD, 2009. Agriculture at a Crossroads-the Global Report. International Assessment of Agricultural Knowledge, Science, and Technology. Island Press, Washington D. C.

IEA, 2009. World Energy Outlook 2009. IEA, Paris.

Interlaboratory Working Group, 1997. Scenarios of U.S. Carbon Reductions Potential Impacts of Energy-Efficient and Low-Carbon Technologies by 2010 and Beyond. Oak Ridge, TN and Berkeley, CA: Oak Ridge National Laboratory and Lawrence Berkeley National Laboratory.

IUCN, UNEP, 2006. The World Database on Protected Areas (WDPA). UNEP-WCMC, Cambridge, UK.

Jacob, K., Münch, L., Werland, S., 2014. Indikatoren der RessourcenpolitikAkteursanalyse von Interessen und Betroffenheit. Debattenanalyse im Projekt Ressourcenpolitik: Analyse der ressourcenpolitischen Debatte und Entwicklung von Politikoptionen (PolRess). Freie Universität, Berlin p. 52.

Jacobson, M.Z., Delucchi, M.A., 2011. Providing all global energy with wind, water, and solar power, Part I: Technologies,energy resources,quantities and areas of infrastructure and materials. Energy Policy 39, 1154-1169.

Kaiser, R., Miehe, A., Emmerich, C., Schwenk, B., 2012. German Resource Efficiency Programme (ProgRess) Federal Ministry for the Environment. Nature Conservation and Nuclear Safety, Berlin, Germany p. 124

Koning, N.B.J., Van Ittersum, M.K., Becx, G.A., Van Boekel, M.A.J.S., Brandenburg, W. A., Van Den Broek, J.A., Goudriaan, J., Van Hofwegen, G., Jongeneel, R.A., Schiere, J.B., Smies, M., 2008. Long-term global availability of food: continued abundance or new scarcity? NJAS - Wageningen J. Life Sci. 55, 229-292.

Kram, T., Stehfest, E.E., 2012. The IMAGE Model Suite used for the OECD Environmental Outlook to 2050. PBL Netherlands Environmental Assessment Agency, Bilthoven p. 44.

Kriegler, E., Weyant, J., Blanford, G., Krey, V., Clarke, L., Edmonds, J., Fawcett, A. Luderer, G., Riahi, K., Richels, R., Rose, S., Tavoni, M., van Vuuren, D., 2014. The role of technology for achieving climate policy objectives: overview of the EMF 27 study on global technology and climate policy strategies. Clim. Change 123, 353-367.

McCollum, D.L., Krey, V., Riahi, K., 2011. An integrated approach to energy sustainability. Nat. Clim. Change 1, 428-429.

MEA, 2005. Ecosystems and Human well-being: Synthesis of the Millennium Ecosystem Assessment. Island Press, Washington D. C.

Mohr, S., Evans, G., 2013. Projections of future phosphorus production. PHILICA. COM Article number 380.

Nelson, G.C., Rosegrant, M.W., Palazzo, A., Gray, I., Ingersoll, C., Robertson, R., Tokgoz, S., Zhu, T., Sulser, T.B., Ringler, C., Msangi, S., You, L., 2010. Food Security, Farming, and Climate Change to 2050: Scenarios, Results, Policy Options. IFPRI Research Monograph International Food Policy Research Institute (IFPRI), Washington D. C p. 115.

Nepstad, D., Irawan, S., Bezerra, T., Boyd, W., Stickler, C., Shimada, J., Carvalho, O. MacIntyre, K., Dohong, A., Alencar, A., Azevedo, A., Tepper, D., Lowery, S., 2013. More food, more forests, fewer emissions, better livelihoods: linking REDD+, sustainable supply chains and domestic policy in Brazil, Indonesia and Colombia. Carbon Manage. 4, 639-658.

Nepstad, D., McGrath, D., Stickler, C., Alencar, A., Azevedo, A., Swette, B., Bezerra, T., DiGiano, M., Shimada, J., Seroa da Motta, R., Armijo, E., Castello, L., Brando, P., Hansen, M.C., McGrath-Horn, M., Carvalho, O., Hess, L., 2014. Slowing Amazon deforestation through public policy and interventions in beef and soy supply chains. Science 344, 1118-1123.

Neumann, K., Verburg, P.H., Stehfest, E., Müller, C., 2010. The yield gap of global grain production: A spatial analysis. Agric. Sys. 103, 316-326.

OECD, 2011. Towards Green Growth, Oecd Green Growth Studies. Organisation for Economic Co-operation and Development, Paris p. 144.

OECD, 2012a. OECD Environmental Outlook to 2050: The Consequences of Inaction. Organisation for Economic Co-operation and Development, Paris p. 350.

OECD, 2012b. Sustainable Materials Management. Organisation for Economic Cooperation and Development, Paris p. 20.

OECD, 2013. Putting Green Growth at the Heart of Development, Oecd Green Growth Studies. Organisation for Economic Co-operation and Development, Paris p. 192.

Polimeni, J.M., Mayumi, K., Giampietro, M., Alcott, B., 2007. The Jevons Paradox and the Myth of Resource Efficiency Improvements. Earthscan.

Prins, A.G., Slingerland, S., Manders, A.J.G., Lucas, P.L., Hilderink, H.B.M., Kok, M.T.J., 2011. Scarcity in a Sea of Plenty? Global Resource Scarcities and Policies in the European Union and the Netherlands. PBL Netherlands Environmental Assessment Agency, The Hague p. 85.

Roorda, C., Neelis, M.L., 2006. Inclusion of production, energy use and value added for steel, cement and paper in the TIMER energy demand module. Copernicus Institute for Sustainable Development and Innovation. Department of Science, Technology and Society, Utrecht.

Rose, S.K., Kriegler, E., Bibas, R., Calvin, K., Popp, A., van Vuuren, D.P., Weyant, J. 2014. Bioenergy in energy transformation and climate management. Clim. Change $123,477-493$

Schandl, H., West, J., 2010. Resource use and resource efficiency in the Asia-Pacific region. Global Environ. Change 20, 636-647.

Schmidhuber, J., Bruinsma, J., Boedeker, G., 2009. Capital requirements for agriculture in developing countries to 2050, FAO Expert Meeting on How to Feed the World in 2050. Food and Agriculture Organization of the United Nations, Rome p. 21.

Scholes, R.J., Biggs, R., 2005. A biodiversity intactness index. Nature 434, 45-49.

Scholz, R.W., Wellmer, F.-W., 2015. Comment on: Recent revisions of phosphate rock reserves and resources: a critique by Edixhoven et al.-phosphate reserves and resources: what conceptions and data do stakeholders need for sustainable action? Earth Syst. Dyn. 6, 31-80.

Schröder, J.J., Smit, A.L., Cordell, D., Rosemarin, A., 2011. Improved phosphorus use efficiency in agriculture: a key requirement for its sustainable use. Chemosphere 84, 822-831.

Smith, P., Gregory, P.J., van Vuuren, D.P., Obersteiner, M., Havlík, P., Rounsevell, M., Woods, J., Stehfest, E., Bellarby, J., 2010. Competition for land. Philos. Trans. R. Soc. B: Biol. Sci. 365, 2941-2957.

Stehfest, E., van den Berg, M., Woltjer, G., Msangi, S., Westhoek, H., 2013. Options to reduce the environmental effects of livestock production-comparison of two economic models. Agric. Syst. 114, 38-53.

Ten Brink, B., van der Esch, S., Kram, T., van Oorschot, M., Alkemade, R., Ahrens, R., Bakkenes, M., Bakkes, J., van den Berg, M., Christensen, V., Janse, J., Jeuken, M., Lucas, P., Manders, T., van Meijl, H., Stehfest, E., Tabeau, A., van Vuuren, D.P., Wilting, H., 2010. Rethinking Global Biodiversity Strategies. Exploring Structural Changes in Production and Consumption to Reduce Biodiversity Loss. PBL-The Netherlands Environmental Assessment Agency, Bilthoven p. 168.

The Royal Society, 2009. Reaping the benefits: Science and the sustainable intensification of global agriculture. In: The Royal Society (Ed.), RS Policy document. The Royal Society, London, London p. 86.

UNEP, 2012. Kenya, p. Responsible Resource Management for a Sustainable World: Findings from the International Resource Panel. United Nations Environment Programme, Nairobi, pp. 36

USGS, 2011. Mineral commodity summaries (http://minerals.usgs.gov/minerals/ pubs/mcs/). United States Geological Survey.

Vaccari, D.A., Strigul, N., 2011. Extrapolating phosphorus production to estimate resource reserves. Chemosphere 84, 792-797.

Van den Berg, M., Bakkes, J., Bouwman, A.F., Jeuken, M., Kram, T., Neumann, K., Van Vuuren, D.P., Wilting, H., 2011. EU Resource Efficiency Perspectives in a Global 
Context. PBL The Netherlands Environmental Assessment Agency, Bilthoven p. 107.

van den Bergh, J., 2011. Energy conservation more effective with rebound policy. Environ. Resour. Econ. 48, 43-58.

Van Drecht, G., Bouwman, A.F., Harrison, J., Knoop, J.M., 2009. Global nitrogen and phosphate in urban wastewater for the period 1970 to 2050. Global Biogeochem. Cycles 23 GB0A03, 19.

Van Kauwenbergh, S.J., Stewart, M., Mikkelsen, R., 2013. World reserves of phosphate rock-a dynamic and unfolding story. Better Crops Plant Food 97, 1820.

Van Vuuren, D.P., den Elzen, M.G.J., Lucas, P., Eickhout, B., Strengers, B., van Ruijven, B.J., Wonink, S., van Houdt, R., 2007. Stabilizing greenhouse gas concentrations at low levels: an assessment of reduction strategies and costs. Clim. Change 81, 119-159.

Van Vuuren, D.P., Faber, A., 2009. Growing within limits. A report to the Global Assembly 2009 of the Club of Rome, PBL publication number 500201001. Netherlands Environmental Assessment Agency (PBL), Bilthoven.

Van Vuuren, D.P., Bouwman, A.F., Beusen, A.H.W., 2010a. Phosphorus demand for the 1970-2100 period: a scenario analysis of resource depletion. Global Environ. Change 20, 428-439.

Van Vuuren, D.P., Stehfest, E., den Elzen, M.G.J., van Vliet, J., Isaac, M., 2010b. Exploring IMAGE model scenarios that keep greenhouse gas radiative forcing below $3 \mathrm{~W} / \mathrm{m}^{2}$ in 2100. Energy Econ. 32, 1105-1120.
Van Vuuren, D.P., Stehfest, E., den Elzen, M.G.J., Kram, T., van Vliet, J., Deetman, S., Isaac, M., Klein Goldewijk, K., Hof, A., Mendoza Beltran, A., Oostenrijk, R., van Ruijven, B., 2011. RCP2.6: Exploring the possibility to keep global mean temperature increase below $2^{\circ} \mathrm{C}$. Clim. Change 109, 95-116.

Van Vuuren, D.P., Kok, M., van der Esch, S., Jeuken, M., Lucas, P., Prins, A.G. Alkemade, R., van den Berg, M., Biermann, F., van der Grijp, N., Hilderink, H., Kram, T., Melamed, C., Pattberg, P., Scott, A., Stehfest, E., de Vries, B., te Velde, D.W., Wiggins, S., 2012. Roads from Rio +20. Pathways to achieve global sustainability goals by 2050. PBL Netherlands Environmental Assessment Agency, The Hague p. 286.

Van Vuuren, D.P., Kok, M. Lucas, P.L, Prins, A.G, Alkemade, R, van den Berg, M. Bouwman, A.F., van der Esch, S., Jeuken, M., Kram, T., Stehfest, E., 2015. Pathways to achieve a set of ambitious global sustainability objectives by 2050 explorations using the IMAGE integrated assessment model. Technol. Forecast. Soc. Change 98, 303-323.

Westhoek, H., Rood, T., van den Berg, M., Janse, J., Nijdam, D., Reudink, M., Stehfest, E., 2011. The Protein Puzzle: The Consumption and Production of Meat, Dairy and Fish in the European Union. PBL Netherlands Environmental Assessment Agency, The Hague p. 218.

Willett, W.C., Skerrett, P.J., Giovannucci, E.L., Callahan, M., 2001. Eat, drink, and be healthy: The Harvard Medical School Guide to Healthy Eating. Simon \& Schuster Source, New York. 